\title{
Assessment of Nutritional Status of Different Genotypes of Common Bean (Phaseolus vulgaris L.)
}

\author{
Luzia Pereira da Silva ${ }^{1}$, Walter Quadros Ribeiro Júnior ${ }^{2}$, Andre Freire $\mathrm{Cruz}^{3}$, Sebastião Alberto de Oliveira ${ }^{1}$ \& \\ Maria Lucrécia Gerosa Ramos ${ }^{1}$ \\ ${ }^{1}$ Universidade de Brasília, Faculdade de Agronomia e Medicina Veterinária, Brasília, DF, Brazil \\ ${ }^{2}$ Embrapa -Centro de Pesquisa Agropecuária dos Cerrados, Planaltina, DF, Brazil \\ ${ }^{3}$ Kyoto Prefectural University - Graduate School of Life and Environmental Sciences, Kyoto 606-8522, Japan \\ Correspondence: Andre Freire Cruz, Kyoto Prefectural University - Graduate School of Life and Environmental \\ Sciences, Shimogamohangi-cho 1-5, Sakyo-ku, Kyoto 606-8522, Japan. Tel/Fax: 81-75-703-5608. E-mail: \\ andre@kpu.ac.jp
}

Received: April 23, 2014 Accepted: May 18, 2015 Online Published: May 21, 2015

doi:10.5539/jps.v4n2p57 URL: http://dx.doi.org/10.5539/jps.v4n2p57

\begin{abstract}
The objective of this study was to evaluate the nutritional state of 20 different genotypes of common bean, which were six cultivars and 14 breeding lines. The experiment was conducted in the field, between August and November of 2002, in an Oxysoil, Cristalina - GO, Brazil. Yield and leaf diagnosis were evaluated, 45 days after the emergence of the culture (total foliar rates of $\mathrm{N}, \mathrm{P}, \mathrm{K}, \mathrm{Ca}, \mathrm{Mg}, \mathrm{S}, \mathrm{B}, \mathrm{Mn}, \mathrm{Cu}$ and $\mathrm{Zn}$ ), by the DRIS method, using the nutrient concentrations, taken two by two. Nutrient absorption was different for the genotypes. In most of them, $\mathrm{Zn}$ was the less absorbed nutrient, while $\mathrm{S}$ was the nutrient in excess. DRIS correlation was different for nutrient interactions, as for a positive correlation for $\mathrm{P} \times \mathrm{Zn}(0,928)$, as for a negative correlation, for $\mathrm{N} \times \mathrm{S}$ $(-0,947)$. DRIS shows nutrient deficiency and nutrient excess, for manure recommendations, and it can be used as a routine for bean culture, based on a leaf diagnosis.
\end{abstract}

Keywords: nutrient uptake, leaf diagnosis, DRIS, yield

\section{Introduction}

The common bean (Phaseolus vulgaris L.) represents an important protein source in Brazil. Due to its easy adaptability to many climatic conditions in this country, it can grown in different regions, and can be cultivated over the year (up to three harvests) using several systems ranging from subsistence farming in small farms to high-tech agriculture on large scale. This crop reached a year production of 3.5 million ton in 2010 (MAPA, 2012), however actually this area decreased to about 4.1 million hectares (Ruas, 2010).

The utilization of high-tech agriculture, especially with irrigation, the production becomes economically viable, including the use of lime, proper fertilization, high yield cultivars, severe control of diseases, pests and weeds (Thung \& Oliveira, 1998).

The bean productivity in Brazil is considered low as compared to the potential of the varieties recommended by researchers. The explanation for this low productivity could be several factors, such as, inadequate farming management, poor soil and lack of using of improved breed varieties, and finally the inappropriate fertilization. In high-tech agriculture, fertilizer application usually occurs with large amounts, increasing production costs, which leads the necessity to optimization of this practice, in order to maximize the yield at low cost (Malavolta, 1992).

However, in cases of insufficiency, excess of imbalance of one or more nutrients the plant growth become restricted, because the nutrients coexist in complex interactions involving energy metabolism, and plant physiology. Thus, deficiency symptoms may be due to low soil nutrient supply or low plant genetic ability to uptake and transport ions, but also by their interaction with other ions (Creste et al, 1999; Schulte \& Kelling, 2002).

Schulte and Kelling (2002) reported the role of plant nutrition analysis to detect the deficiency, toxicity or non-balance of nutrients, identifying especially "hidden hunger", to assess fertilization programs. This 
information determines the availability of elements not detected by other methods, the interaction between nutrients and completes the soil nutritional analysis.

To provide more data besides the chemical analysis of soil, the leaf analysis quantitatively can determine the nutrients concentration in plant tissues, which allows an assessment of plant nutritional status in situ (Bonilla \& Bolaños, 2010; Creste et al., 1999). The plant nutrient analysis of a specific organ at a phonological stage have been used to evaluate the nutritional status and in the fertilizer recommendation (Creste \& Echer, 2010; Malavolta et al., 1998).

The DRIS (Diagnosis and Recommendation Integrated System) is a method to understand leaf analysis, which takes into account all interactions between nutrients and minimize the main limiting factors for the critical level method. The DRIS method uses the ratios between the concentrations of nutrients to understand the leaves and soil (Malavolta et al, 1998; Schulte \& Kelling, 2002). The utilization of DRIS can alleviate the effects of nutrients concentration or dilution on dry matter. When the DRIS value become negative, suggests that the plant is deficient in those nutrients, otherwise the positive values indicate the excess of nutrients, and near the zero means that the plants are nutritionally balanced (Lana et al., 2010).

Costa (2002) used the DRIS system in commercial bean farms in Jussara city (Goiás state, Brazil), whose preliminary results showed that the method has been effective to diagnosis the crop nutritional status. This indicates non-balance degree and the range between the excess and deficiency, which are fundamental for fertilizer recommendation.

According to Schulte and Kelling (2002), the advantage of DRIS system would be that the growth stage, plant parts and cultivars are not essential to detect the critical level of a particular nutrient. However, a research conducted by Wadt et al. (1999) and Silveira (2000) with eucalyptus and Ferreira (2003) in Heliconia latispatha using the DRIS demonstrated a distinct behavior according to the evaluated genotype.

The current research aimed to assess the nutritional status through the DRIS method in different bean genotypes, observing the differences between cultivars to seek a understanding of the evaluated traits. (foi isso que vc quis dizer)

\section{Materials and Methods}

The study was conducted at Pantanal Farm, owned by Prezzoto Sementes Company Ltd., Crystalline City, Goias State, Brazil. on an clay texture Red Oxisol. The weather was defined as Aw (Köppen), with two distinct seasons (wet and dry). The experimental area was primarily used for pasture, and for the implementation the bean was sown in 2002.

The experimental design was composed by a randomized block design with three replicates. The plot size was 5 $\times 3 \mathrm{~m}$, with a space of $0.50 \mathrm{~m}$ between rows having 12 plants per $\mathrm{m}$, where $0.5 \mathrm{~m}$ of the boarder lines was deducted, totaling $6 \mathrm{~m}^{2}$ area per plot. The three central rows within each plot were chosen for planta analysis ahd yield.

Soil analysis was performed before the experiment: $\mathrm{pH}$ in water, 5,2; Organic Matter, $55 \mathrm{~g} \mathrm{dm}^{-3} ; \mathrm{Al}^{3+}, 0.03 \mathrm{cmol}_{\mathrm{c}}$ $\mathrm{dm}^{-3} ; \mathrm{Ca}^{2+}+\mathrm{Mg}^{2+}, 4.29 \mathrm{cmol}_{\mathrm{c}} \mathrm{dm}^{-3} ; \mathrm{H}^{+}+\mathrm{Al}^{3+}, 8.26 \mathrm{cmol}_{\mathrm{c}} \mathrm{dm}^{-3} ; \mathrm{P}, 18,3 \mathrm{mg} \mathrm{dm} \mathrm{K}^{-3} ; 0,10 \mathrm{cmol}_{\mathrm{c}} \mathrm{dm}^{-3}$. The soil amendment and fertilization (600 kg / ha of NPK 7-21-16 + FTE BR-12 and $200 \mathrm{~kg} /$ ha of ammonium sulfate at 22 DAE) were applied based in the fifth matching and according to technical recommendations for bean from EMBRAPA-Brazil (Stone \& Sartorato, 1994).

In August 17, 2002 the bean was sown and the weeds and pests control were done as usual in the farm where the experiment was located. Considering the topography and the existence of sub-soil water a sub-surface irrigation (by capillarity) was used too.

Six cultivars of beans and 14 lines were used, composing 20 genotypes as follows: FT-84-105, FT-Nobre, FT-97-512, FT-97-708, FT-91-625, FT-Soberano, FT-97-837, FT-91-3168, FT-206, FT-9768, FT-96-1117, FT-Magnifico, FT-97-176, FT-97-119, FT-84-113, FT-90-1535, FT-97-255, Carioca, Bonito and Bionobre, provided by FT - Sementes Ltda. The agronomic characteristics of these genotypes, obtained in different assays are described in Table 1.

Five plants were randomly collected from each plot for leaf analysis 45 days after crop seeding. From these plants the first young leaves from the apical part were removed (Oliveira, 2002). Then the samples were drought in oven at $70{ }^{\circ} \mathrm{C}$ for 72 hours, ground and $20 \mathrm{~g}$ was taken for macro and micronutrients analysis, performed at the Laboratory of Soil Fertility and Plant Nutrition of CAMPO Co., Paracatu City - Minas Gerais-Brazil.

The nutrients N, P, K, Ca, Mg, S, B, Zn, Fe, Mn and $\mathrm{Cu}$ were determined, whose concentrations were expressed 
in $\mathrm{g} \mathrm{kg}^{-1}$ and for macronutrients $\mathrm{m} \mathrm{kg}^{-1}$ for the micronutrients. The leaf tissue analysis was performed according to the methods described by Malavolta et al. (1998).

Table 1. Agronomical characteristics of the bean genotypes used in the experiment, as informed by FT- Sementes Ltda, Brazil

\begin{tabular}{|c|c|c|c|c|c|c|c|c|c|c|}
\hline Genotype & Grain & $\mathrm{d}(1$ & Standar & $\mathrm{kg} / \mathrm{ha}(2$ & $\operatorname{mber}(3$ & Stability(4)A & Antrac.(5) & ) $\mathrm{FS}(6) \mathrm{C}$ & Curtobac.(7) & Type(8) \\
\hline FT 91-3168 & Carioca & 99 & Pérola & 2341 & 26 & 15 in 26 & $\mathrm{R}$ & $4,4,0,0$ & $1,2,2$ & SP \\
\hline FT 91-625 & Carioca & 96 & Pérola & 2341 & 26 & 14 in 26 & $\mathrm{R}$ & $4,4,2,0$ & $2,3,2$ & $\mathrm{SE} / \mathrm{E} / \mathrm{SP}$ \\
\hline FT 97-68 & Carioca & 93 & Pérola & 2341 & 26 & 11 in 26 & $\mathrm{R}$ & $4,3,2,1$ & $2,1,1$ & $\mathrm{SE}-\mathrm{SP} / \mathrm{SE}$ \\
\hline FT Magnífico & Carioca & 116 & Pérola & 2341 & 26 & 25 in 26 & MR & $0,0,0,0$ & $2,3,2$ & $\mathrm{P} / \mathrm{SP}$ \\
\hline FT 97-175 & Carioca & 116 & Pérola & 2341 & 26 & 25 in 26 & MR & $0,0,0,0$ & $2,3,2$ & $\mathrm{P} / \mathrm{SP}$ \\
\hline FT 97-119 & Carioca & 99 & Pérola & 2341 & 26 & 16 in 26 & $\mathrm{AE}$ & $1,1,0,0$ & $2,1,2$ & $\mathrm{SE} / \mathrm{SP}$ \\
\hline FT 90-1535 & Carioca & 104 & Pérola & 2341 & 17 & 13 in 17 & MS & $0,5,1,3$ & SI & SP \\
\hline FT 97-255 & Carioca & 99 & Pérola & 2341 & 17 & 14 in 17 & AS & $3,1,0,1$ & $2,3,2$ & $\mathrm{E} / \mathrm{SE}$ \\
\hline Carioca & Carioca & 102 & Pérola & 2341 & 17 & 18 in 26 & S & $4,5,0,1$ & SI & $\mathrm{P}$ \\
\hline Bonito & Carioca & 101 & Pérola & 2341 & 10 & 6 in 10 & MS & SI & SI & SP \\
\hline FT206 & (9) & (9) & (9) & (9) & (9) & (9) & (9) & (9) & (9) & (9) \\
\hline FT 84-105 & Preto & 96 & Nobre & 2340 & 19 & 13 in 19 & AR & $3,5,2,0$ & SI & SE - P \\
\hline FT 84-105 & Preto & 96 & Nobre & 2340 & 19 & 13 in 19 & $\mathrm{AR}$ & $3,5,2,0$ & SI & SE - P \\
\hline FT 97-512 & Preto & 95 & Nobre & 2340 & 19 & 9 in 19 & MR & $3,5,0,0$ & SI & E/SE - P \\
\hline FT 97-708 & Preto & 97 & Nobre & 2340 & 19 & 10 in 19 & MS & $5,5,4,5$ & SI & E-SP \\
\hline Soberano & Preto & 109 & Nobre & 2340 & 19 & 13 in 19 & $\mathrm{AR}$ & $0,0,0,1$ & SI & $\mathrm{SP} / \mathrm{P}-\mathrm{SE}$ \\
\hline FT 97-837 & Preto & 94 & Nobre & 2340 & 19 & 9 in 19 & MR & $0,2,0,0$ & SI & $\mathrm{E} / \mathrm{SE}$ \\
\hline FT 96-1117 & Preto & 110 & Nobre & 2340 & 19 & 12 in 19 & $\mathrm{AR}$ & $2,3,2,5$ & SI & $\mathrm{SP} / \mathrm{SE}$ \\
\hline FT 84-113 & Preto & 97 & Nobre & 2340 & 19 & 11 in 19 & MR & $4,5,2,5$ & SI & $\mathrm{SE} / \mathrm{SP}$ \\
\hline Bionobre & Preto & 101 & Nobre & 2341 & 19 & 12 in 19 & AS & $2,0,0,0$ & SI & SE/SP P \\
\hline
\end{tabular}

1) Relative productivity compared to the standard (\%).

2) Average productivity $\left(\mathrm{kg} \mathrm{ha}^{-1}\right)$ of the standard.

3) Total number of assays.

4) Number of assays equals of greater than the standard.

5) R(resistant), AR (strongly resistant), MS (moderate susceptible), S (susceptible), AS (strongly susceptible).

6) Soil fungus (Fusarium and Rhizoctonia) - 0 to 5.

7) Curtobactérium (0 a 5) - $\mathrm{SI}=$ no information.

8) Type: E (Straight), P (supported), SE-SP (semi-straight or semi-supported).

9) Data not informed.

The grain yield was determined at 90 days after seeding, when the plants reached the physiological maturity, with the grain mass moisture corrected to $13 \%$. The concentration of the nutrients $\mathrm{N}, \mathrm{P}, \mathrm{K}, \mathrm{Ca}, \mathrm{Mg}, \mathrm{S}, \mathrm{B}, \mathrm{Zn}, \mathrm{Fe}$, $\mathrm{Mn}$ and $\mathrm{Cu}$ in leaves and yield $\left(\mathrm{kg} \mathrm{ha}^{-1}\right)$ were used as a database for DRIS application (Beaufils, 1973; Creste et al, 1999; Costa, 2002).

The DRIS index estimation was done by merging the genotypes based on average yield in two groups: group A (productivity less than $3000 \mathrm{~kg} \mathrm{ha}^{-1}$ ), and group B, with yield equal or more than $3000 \mathrm{~kg} \mathrm{ha}^{-1}$. The Group B was considered high yield ones denominated "control group" as described in Table 2.

The DRIS rates obtained from different bean genotypes were calculated using computer software developed by 
Prof Sebastiao Oliveira, (University of Brasilia - Brazil) (Lana et al., 2010; Oliveira et al., 2009).

Table 2. Leaf concentration of macro e micronutrients and productivity of 20 bean genotypes (average of three replicates)

\begin{tabular}{lccccccccccccc}
\hline \multirow{2}{*}{ Genotypes } & $\mathrm{N}$ & $\mathrm{P}$ & $\mathrm{K}$ & $\mathrm{Ca}$ & $\mathrm{Mg}$ & $\mathrm{S}$ & $\mathrm{B}$ & $\mathrm{Cu}$ & $\mathrm{Fe}$ & $\mathrm{Mn}$ & $\mathrm{Zn}$ & Yield \\
\cline { 2 - 11 } & \multicolumn{7}{c}{$\mathrm{g} / \mathrm{kg}$} \\
\hline FT-84-105 & 36.30 & 3.40 & 23.10 & 27.77 & 5.23 & 3.00 & 61.7 & 13.0 & 348.7 & 266.3 & 32.7 & 1846.66 \\
FT-Nobre & 34.77 & 4.07 & 28.17 & 24.55 & 5.25 & 3.10 & 72.4 & 13.0 & 386.0 & 283.0 & 38.3 & 3714.07 \\
FT-512 & 36.04 & 3.70 & 28.67 & 22.4 & 4.70 & 2.94 & 78.3 & 13.1 & 350.3 & 204.3 & 35.0 & 2962.00 \\
FT-97-708 & 35.77 & 3.70 & 28.67 & 22.4 & 4.70 & 2.94 & 56.3 & 13.3 & 350.3 & 204.3 & 35.0 & 3892.65 \\
FT-91-625 & 41.90 & 3.74 & 26.40 & 21.47 & 4.64 & 2.97 & 66.0 & 13.0 & 330.7 & 281.0 & 34.7 & 2487.77 \\
FT-Soberano & 40.34 & 3.85 & 24.30 & 25.57 & 4.87 & 2.74 & 70.7 & 13.0 & 309.0 & 255.3 & 34.3 & 2942.22 \\
FT-97-837 & 35.04 & 3.54 & 25.20 & 23.06 & 4.03 & 2.74 & 74.7 & 12.0 & 328.0 & 234.7 & 36.0 & 2591.11 \\
FT-91-3168 & 39.07 & 3.37 & 27.13 & 20.43 & 5.03 & 2.77 & 80.7 & 10.3 & 355.7 & 210.3 & 34.0 & 3436.74 \\
FT-206 & 41.53 & 3.77 & 28.27 & 23.3 & 13.80 & 3.34 & 68.0 & 12.3 & 300.0 & 243.3 & 35.7 & 3513.41 \\
FT-9768 & 37.36 & 3.87 & 28.36 & 21.80 & 5.06 & 2.80 & 63.0 & 14.3 & 303.0 & 214.7 & 34.7 & 4109.63 \\
FT-1117 & 40.00 & 3.53 & 27.57 & 23.24 & 4.77 & 2.64 & 68.0 & 13.3 & 331.3 & 247.3 & 35.3 & 3024.37 \\
FT-Magnífico & 39.30 & 4.03 & 24.40 & 23.83 & 6.77 & 2.96 & 82.0 & 14.0 & 418.7 & 246.7 & 36.7 & 3810.81 \\
FT-97-176 & 32.53 & 3.43 & 29.73 & 21.03 & 5.47 & 3.23 & 67.7 & 12.7 & 296.0 & 248.3 & 29.7 & 4208.15 \\
FT-97-119 & 36 & 3.20 & 20.80 & 20.63 & 5.5 & 2.63 & 62.0 & 11.0 & 344.3 & 189.7 & 32.7 & 3757.85 \\
FT-84-113 & 40.3 & 3.30 & 25.67 & 21.33 & 4.13 & 2.70 & 56.3 & 12.0 & 265.3 & 200.3 & 30.0 & 3690.37 \\
FT-90-1535 & 34.5 & 3.50 & 25.40 & 21.2 & 5.17 & 2.97 & 65.7 & 12.3 & 310.0 & 192.7 & 29.3 & 2636.82 \\
FT-97-255 & 34.26 & 3.63 & 27.17 & 20.5 & 4.87 & 3.17 & 70.7 & 12.3 & 519.3 & 235.7 & 33.0 & 1328.37 \\
Carioca & 34.8 & 3.53 & 23.36 & 22.8 & 5.40 & 2.83 & 64.0 & 12.7 & 360.7 & 213.3 & 33.0 & 1897.11 \\
Bonito & 36.03 & 3.83 & 24.80 & 23.66 & 5.00 & 2.90 & 73.7 & 14.0 & 247.7 & 261.0 & 33.7 & 3467.78 \\
Bionobre & 33.53 & 3.43 & 26.93 & 21.8 & 4.40 & 2.96 & 69.0 & 11.7 & 298.0 & 221.3 & 33.0 & 1767.93 \\
\hline
\end{tabular}

\section{Results and Discussion}

The nutrients concentration in leaves and productivity of the genotypes are shown in Table 2. Leaf analysis genotypes corroborates with the data of macro and micronutrients which are appropriate for the beans, described by Malavolta et al. (1998). The yield ranged from 1328 to $4208 \mathrm{~kg} \mathrm{ha}^{-1}$ (Table 2).

The calculation of DRIS index for each nutrient in all genotypes and the series values were obtained. Then these values were ranked within each series, in order of limitation importance, the criteria in descending order (Table 3) was used. When the index was more negative, the nutrient limitation was higher, and more positive indicates less limiting and depending on the situation by limiting excess.

The results in Table 3 showed that $\mathrm{Zn}$ was the most limiting nutrient in $40 \%$ of the genotypes, whose yields were below than those of the Group B, in $55.5 \%$ of cases. B and K were the most limiting in $15 \%$ of cases, and $66.6 \%$ of these belonged to control group. The $\mathrm{Fe}$ and $\mathrm{S}$ had the same level of limitation, $10 \%$, and the yields obtained were lower than the standards in $50 \%$ of the genotypes. And finally, the most limiting nutrients were $\mathrm{N}$ and $\mathrm{Cu}$ with $5 \%$ of occurrences in the control group. $\mathrm{P}, \mathrm{Ca}, \mathrm{Mg}$ and $\mathrm{Mn}$ had not any results in terms of limitation in any situation. In summary, the limitation sequence of nutrient scarcity in the genotypes in percentages was as follows: $\mathrm{Zn}(40 \%)>\mathrm{K}=\mathrm{B}(15 \%)>\mathrm{S}=\mathrm{Fe}(10 \%)>\mathrm{N}=\mathrm{Cu}(5 \%)>=\mathrm{P}=\mathrm{Ca}=\mathrm{Mg}=\mathrm{Mn}(0 \%)$.

Among 20 analyzed genotypes, $40 \%$ (eight) showed the $\mathrm{S}$ as the nutrient most limiting by excess. Within this group, 75\% (six) had $\mathrm{Zn}$ as the most limiting nutrient for scarcity. And in both genotypes and FT-97-837 and FT1117, where the $\mathrm{S}$ was considered the limiting by scarcity, $\mathrm{Zn}$ was the limiting nutrient by excess, suggesting a trend of antagonism between these two elements i.e. the $\mathrm{S}$ and $\mathrm{Zn}$ are contradictory in terms of absorption in plants. Other nutrients have been limiting for excess: $\mathrm{Mg}$ (genotypes), Ca (two), $\mathrm{K}$ (two), Mn (one), B (one) and 
$\mathrm{Cu}$ (one) (Table 3).

Table 3. Primary DRIS index and limiting sequence of nutrients in different bean genotypes

\begin{tabular}{|c|c|c|c|c|c|c|c|c|c|c|c|c|}
\hline \multirow{2}{*}{ Genotype } & \multicolumn{11}{|c|}{ DRIS index } & \multirow{2}{*}{ Limiting sequence } \\
\hline & $\mathrm{N}$ & $\mathrm{P}$ & $\mathrm{K}$ & $\mathrm{Ca}$ & $\mathrm{Mg}$ & $\mathrm{S}$ & $\mathrm{B}$ & $\mathrm{Cu}$ & $\mathrm{Fe}$ & $\mathrm{Mn}$ & $\mathrm{Zn}$ & \\
\hline FT-84-105 & -62 & -55 & -55 & 111 & 33 & 95 & -81 & 23 & -36 & 59 & -115 & $\mathrm{Zn}>\mathrm{B}>\mathrm{N}>\mathrm{P}=\mathrm{K}>\mathrm{Fe}>\mathrm{Cu}>\mathrm{Mg}>\mathrm{Mn}>\mathrm{S}>\mathrm{Ca}$ \\
\hline FT-Nobre & -32 & 31 & 7 & 31 & 123 & 31 & 32 & 6 & 32 & 48 & 42 & $\mathrm{~N}>\mathrm{Cu}>\mathrm{K}>\mathrm{Mg}>\mathrm{P}=\mathrm{S}=\mathrm{Ca}>\mathrm{B}=\mathrm{Fe}>\mathrm{Zn}>\mathrm{Mn}$ \\
\hline FT-512 & -35 & -13 & 41 & -27 & -203 & 37 & -45 & -3 & -17 & -34 & -31 & $\mathrm{~B}>\mathrm{N}>\mathrm{Mn}>\mathrm{Zn}>\mathrm{Ca}>\mathrm{Mg}>\mathrm{Fe}>\mathrm{P}>\mathrm{Cu}>\mathrm{S}>\mathrm{K}$ \\
\hline FT97-708 & -34 & -11 & 41 & -10 & -243 & 39 & -80 & 18 & -16 & -34 & -32 & $\mathrm{~B}>\mathrm{N}=\mathrm{Mn}>\mathrm{Zn}>\mathrm{Mg}>\mathrm{Fe}>\mathrm{P}>\mathrm{Ca}>\mathrm{Cu}>\mathrm{S}>\mathrm{K}$ \\
\hline FT-91-625 & 4 & -5 & 36 & -19 & -26 & 67 & -5 & -6 & -52 & 40 & -37 & $\mathrm{Fe}>\mathrm{Zn}>\mathrm{Mg}>\mathrm{Ca}>\mathrm{Cu}>\mathrm{B}=\mathrm{P}>\mathrm{N}>\mathrm{K}>\mathrm{Mn}>\mathrm{S}$ \\
\hline FT-Soberano & 36 & 17 & -54 & 75 & $-5-$ & -35 & 12 & 23 & 0 & 47 & 26 & $\mathrm{~K}>\mathrm{S}>\mathrm{Mg}>\mathrm{Fe}>\mathrm{B}>\mathrm{P}>\mathrm{Cu}>\mathrm{Zn}>\mathrm{N}>\mathrm{Mn}>\mathrm{Ca}$ \\
\hline FT-97-837 & 29 & 30 & -13 & 36 & $-43-$ & -50 & 62 & -16 & 32 & 37 & 96 & $\mathrm{~S}>\mathrm{Mg}>\mathrm{Cu}>\mathrm{K}>\mathrm{N}>\mathrm{P}>\mathrm{Fe}>\mathrm{Ca}>\mathrm{Mn}>\mathrm{B}>\mathrm{Zn}$ \\
\hline FT-91-3168 & 1 & -30 & 7 & -87 & 20 & -31 & 102 & -104 & 29 & -33 & 8 & $\mathrm{Cu}>\mathrm{Ca}>\mathrm{Mn}>\mathrm{P}>\mathrm{S}>\mathrm{N}>\mathrm{K}>\mathrm{Zn}>\mathrm{Mg}>\mathrm{Fe}>\mathrm{B}$ \\
\hline FT-206 & -60 & -61 & 78 & -66 & -501 & $157-$ & -46 & -49 & -128 & -3 & -143 & $\mathrm{Zn}>\mathrm{Fe}>\mathrm{Ca}>\mathrm{P}>\mathrm{N}>\mathrm{Mg}>\mathrm{Cu}>\mathrm{B}>\mathrm{Mn}>\mathrm{K}>\mathrm{S}$ \\
\hline FT-9768 & -6 & 19 & 28 & -19 & -10 & $1-$ & -29 & 35 & -23 & -19 & -7 & $\mathrm{~B}>\mathrm{Fe}>\mathrm{Ca}=\mathrm{Mn}>\mathrm{Mg}>\mathrm{Zn}>\mathrm{N}>\mathrm{S}>\mathrm{P}>\mathrm{K}>\mathrm{Cu}$ \\
\hline FT-1117 & 58 & 28 & -30 & 48 & $-21-$ & -85 & 18 & 21 & 38 & 24 & 81 & $\mathrm{~S}>\mathrm{K}>\mathrm{Mg}>\mathrm{B}>\mathrm{Cu}>\mathrm{Mn}>\mathrm{P}>\mathrm{Fe}>\mathrm{Ca}>\mathrm{N}>\mathrm{Zn}$ \\
\hline FT-Magnífico & -15 & 11 & -81 & 6 & $119-$ & -31 & 72 & -9 & 87 & -4 & 17 & $\mathrm{~K}>\mathrm{S}>\mathrm{N}>\mathrm{Cu}>\mathrm{Mn}>\mathrm{Ca}>\mathrm{P}>\mathrm{Zn}>\mathrm{B}>\mathrm{Fe}>\mathrm{Mg}$ \\
\hline FT-97-176 & -210 & -111 & 152 & -139 & 313 & $350-$ & -69 & -48 & -210 & -2 & -333 & $\mathrm{Zn}>\mathrm{Fe}=\mathrm{N}>\mathrm{Ca}>\mathrm{P}>\mathrm{B}>\mathrm{Cu}>\mathrm{Mn}>\mathrm{Mg}>\mathrm{K}>\mathrm{S}$ \\
\hline FT97-119 & 0 & -18 & -81 & 8 & $83-$ & -40 & 24 & -28 & 80 & -32 & 9 & $\mathrm{~K}>\mathrm{S}>\mathrm{Mg}>\mathrm{Cu}>\mathrm{P}>\mathrm{N}>\mathrm{Ca}>\mathrm{Zn}>\mathrm{B}>\mathrm{Fe}>\mathrm{Mg}$ \\
\hline FT-84-113 & -11 & -57 & 45 & -31 & -548 & $81-$ & -86 & -11 & -111 & -21 & -124 & $\mathrm{Zn}>\mathrm{Fe}>\mathrm{B}>\mathrm{P}>\mathrm{Mg}>\mathrm{Ca}>\mathrm{Mn}>\mathrm{Cu}=\mathrm{N}>\mathrm{K}>\mathrm{S}$ \\
\hline FT-90-1535 & -138 & -91 & 71 & -103 & 422 & $210-$ & -61 & -44 & -123 & -50 & -241 & $\mathrm{Zn}>\mathrm{N}>\mathrm{Fe}>\mathrm{Ca}>\mathrm{P} . \mathrm{B}>\mathrm{Mn}>\mathrm{Cu}>\mathrm{Mg}>\mathrm{K}>\mathrm{S}$ \\
\hline FT-97-255 & -114 & -47 & 104 & -109 & -22 & 204 & -5 & -45 & -129 & 0 & -164 & $\mathrm{Zn}>\mathrm{Fe}>\mathrm{N}>\mathrm{Ca}>\mathrm{P}>\mathrm{Cu}>\mathrm{B}>\mathrm{Mg}>\mathrm{Mn}>\mathrm{K}>\mathrm{S}$ \\
\hline Carioca & -46 & -21 & -34 & 14 & 613 & $34-$ & -14 & -2 & 22 & -10 & -47 & $\mathrm{Zn}>\mathrm{N}>\mathrm{K}>\mathrm{P}>\mathrm{B}>\mathrm{Mn}>\mathrm{Cu}>\mathrm{Ca}>\mathrm{Fe}>\mathrm{S}>\mathrm{Mg}$ \\
\hline Bonito & -34 & 12 & 15 & 13 & -57 & 75 & 13 & 32 & -96 & 57 & -63 & $\mathrm{Fe}>\mathrm{Zn}>\mathrm{N}>\mathrm{Mg}>\mathrm{P}>\mathrm{Ca}=\mathrm{B}>\mathrm{K}>\mathrm{Cu}>\mathrm{Mn}>\mathrm{S}$ \\
\hline Bionobre & -72 & -37 & 64 & -51 & -241 & 119 & -2 & -41 & -75 & 3 & -88 & $\mathrm{Zn}>\mathrm{Fe}>\mathrm{N}>\mathrm{ca}>\mathrm{Cu}>\mathrm{P}>\mathrm{Mg}>\mathrm{B}>\mathrm{Mn}>\mathrm{K}>\mathrm{S}$ \\
\hline
\end{tabular}

The excess $\mathrm{S}$ and the $\mathrm{Zn}$ deficiency might be related to the soil richness in organic matter (OM), because it can induce to this situation (Fageria, 2002; Oliveira et al., 1996). The fact that in most of the genotypes the S was the limiting nutrient by excess may be due to the application of ammonium sulfate as cover fertilizer and / or because of the high amount of OM in the soil experiment. According to Oliveira et al. (1996), soils rich in OM that received high doses of $\mathrm{P}$ and areas that were planned or soil moved from surface may exhibit $\mathrm{Zn}$ deficiency. In the present experiment the $P$ dosage used was the one recommended for the crop, but the experiment place has the same characteristics as described above. This may explain the limitation of $\mathrm{Zn}$ by scarcity. Thung \& Oliveira (1998) reported that the $\mathrm{S}$ concentration in bean leaves increases until the end of crop cultivation.

The productivity of the genotypes that presented the $\mathrm{Zn}$ as limiting nutrient by scarcity was below to those of "control group" in five genotypes, however in three of them it was higher, suggesting that despite of DRIS analysis indicate $\mathrm{Zn}$ limitation by scarcity, the productivity was not affected (Table 3). According to Oliveira et al. (1996) there are varieties of bean less susceptible to $\mathrm{Zn}$ deficiency, which enables the beans cropping even in soil poor with Zn deficiency.

In the genotype FT-Nobre, where $\mathrm{N}$ was the strongest limiting factor, Mn showed the highest index, suggesting that despite of $\mathrm{Mn}$ to be a toxic element, when in excess, the general conditions of the plot did not show their deleterious effect (Table 2 and 3).

For the genotypes FT-Magnifico and FT97-119, it was observed that K and Mg were the most and least limiting nutrients respectively, indicating that the excess of Mg affected the uptake of $\mathrm{K}$ in these genotypes (Table 3). This result corroborates with Malavolta et al. (1998), who reported that excess of Mg leads to lack of Ca and $\mathrm{K}$.

The Table 3 presents a scarcity of B in three genotypes (FT-512, FT-97-708, FT-9768) which can be explained by 
its low mobility in plants (Malavolta et al., 1998), probably these genotypes have more difficulty to mobilize B than others. The B has a low range between sufficient concentration in substrate and toxic level, and the relative tolerance of plants to toxicity is linked to transportation rate from roots to shoots (Malavolta et al., 1998). In the case of FT-91-3168, the B excess could be attributed to the phenomenon mentioned above.

The availability of Fe is reduced in flooded soils (Oliveira et al., 1996). The genotypes FT-91-625 and Bonito, where there was scarcity of $\mathrm{Fe}$, may be due to the sub-surface irrigation during the experiment and/or to big sensitivity of these materials to flood (Table 3).

Oliveira et al. (1996) reported that bean does not respond to potassium fertilization, similar situation observed in this experiment, because $66.6 \%$ of the genotypes that showed $\mathrm{K}$ as the most limiting by scarcity belong to the "control group".

Phosphorus has most increased the beans production compared to other elements (Malavolta, 1987; Oliveira et al., 1996; Westermann, 2011). In the currently research, the $\mathrm{P}$ was not limiting by scarcity nor excess, because due to fertilization applied with and appropriate $\mathrm{P}$ concentration, made difficult the detection of genotypes tolerant to $\mathrm{P}$ deficiency.

The potassium, boron, sulfur and copper showed an interesting role in this experiment, limiting by deficiency and excess, which indicates the sensitivity of these nutrients to the fertilizer management. Costa (2002), when using DRIS in irrigated commercial beans, found the following results: $\mathrm{N}, \mathrm{P}, \mathrm{K}$ and $\mathrm{Cu}$ as limiting by scarcity and $\mathrm{Mn}, \mathrm{Cu}$ and $\mathrm{Zn}$ limiting by excess. Some genotypes of this study behaved similarly: $\mathrm{N}, \mathrm{K}$ and $\mathrm{Cu}$ limiting by scarcity and $\mathrm{Mn}, \mathrm{Cu}$ and $\mathrm{Zn}$ by excess (Table 3 ).

The correlation matrix between DRIS rates for different bean genotypes (Table 4) led to identify interactions between nutrients estimating the necessity for fertilizations in the future. In the genotypes could be observed that the highest positive correlations between the nutrients levels were: $\mathrm{P} \times \mathrm{Zn}(0.928), \mathrm{N} \times \mathrm{Zn}(0.920), \mathrm{Fe} \times \mathrm{Zn}$ (0.885), $\mathrm{K} \times \mathrm{S}(0.829), \mathrm{N} \times \mathrm{P}(0.823), \mathrm{N} \times \mathrm{Fe}(0.754)$ and $\mathrm{Ca} \times \mathrm{Cu}(0.735)$. Negative correlations were: $\mathrm{S} \times \mathrm{Zn}$ $(-0.963), \mathrm{N} \times \mathrm{S}(-0.947), \mathrm{S} \times \mathrm{Fe}(-0.908), \mathrm{K} \times \mathrm{Fe}(-0869), \mathrm{P} \times \mathrm{S}(-0.855)$ and $\mathrm{K} \times \mathrm{Ca}(-0.815)$. However, to construct the correlation matrix between DRIS rates the data of all genotypes were used together, and would be interesting to make this correlation matrix for each genotype. Epstein (1975) pointed out that chemical analyzes of different varieties of same species grown in similar environments, can vary widely in the plant tissue nutrient concentration.

According to Malavolta et al. (1998), the excess of P can cause deficiency of heavy metals such as $\mathrm{Fe}, \mathrm{Cu}, \mathrm{Zn}$ and $\mathrm{Mn}$, thus the higher level of this nutrient increase the necessity of the other, i.e. they correlate negatively. In the currently research, the $\mathrm{P}$ content was in the proper range thus there was a negative correlation of $\mathrm{P}$ with the heavy metals mentioned above. $\mathrm{N}$ and $\mathrm{P}$ are the most limiting factors in bean production, confirming the positive correlation found (Thung \& Oliveira, 1998).

The values of Nutritional Balance Index (NBI) of the genotypes ranged from 192 to 1655. In DRIS applied to bean in low productivity crops (lower than $300 \mathrm{~kg} \mathrm{ha}^{-1}$ ), when the NBI was below 30 , the limiting factor in the productivity is not nutrition, however above 60 the productivity was limited by a nutritional factors (Costa, 2002). This author had NBI values ranging between 26 and 220, lower than those in this research. The Figure 1 shows the effect of NBI on bean productivity, but there was no correlation between them. Costa (2002) demonstrated that although the correlation value has not been shown, the graph indicates a correlation between NBI and productivity. However, as the conditions of each experiment are different and the study of DRIS on bean is recent, all of comparisons of different studies should be carefully done. 
Table 4. Correlation matrix between the DRIS rate in different bean genotypes

\begin{tabular}{|c|c|c|c|c|c|c|c|c|c|c|c|}
\hline & $\mathrm{N}$ & $\mathrm{P}$ & $\mathrm{K}$ & $\mathrm{Ca}$ & $\mathrm{Mg}$ & $\mathrm{S}$ & B & $\mathrm{Cu}$ & $\mathrm{Fe}$ & $\mathrm{Mn}$ & $\mathrm{Zn}$ \\
\hline $\mathrm{N}$ & 1,000 & 0.823 & $-0,713$ & 0,673 & $-0,195$ & $-0,947$ & 0,496 & 0,393 & 0,754 & 0,255 & 0,920 \\
\hline $\mathrm{P}$ & & 1,000 & $-0,613$ & 0,657 & $-0,081$ & $-0,855$ & 0,586 & 0,568 & 0,745 & 0,416 & 0,928 \\
\hline $\mathrm{K}$ & & & 1,000 & $-0,815$ & $-0,455$ & 0,829 & $-0,473$ & $-0,400$ & $-0,869$ & $-0,267$ & $-0,734$ \\
\hline $\mathrm{Ca}$ & & & & 1,000 & 0,049 & $-0,704$ & 0,149 & 0,735 & 0,630 & 0,612 & 0,672 \\
\hline $\mathrm{Mg}$ & & & & & 1,000 & $-0,048$ & 0,284 & $-0,104$ & 0,378 & $-0,178$ & $-0,043$ \\
\hline $\mathrm{S}$ & & & & & & 1,000 & $-0,565$ & $-0,400$ & $-0,908$ & $-0,153$ & $-0,963$ \\
\hline B & & & & & & & 1,000 & $-0,242$ & 0,634 & 0,199 & 0,649 \\
\hline $\mathrm{Cu}$ & & & & & & & & 1,000 & 0,246 & 0,475 & 0,372 \\
\hline $\mathrm{Fe}$ & & & & & & & & & 1,000 & 0,059 & 0,885 \\
\hline $\mathrm{Mn}$ & & & & & & & & & & 1,000 & 0,269 \\
\hline $\mathrm{Zn}$ & & & & & & & & & & & 1,000 \\
\hline
\end{tabular}

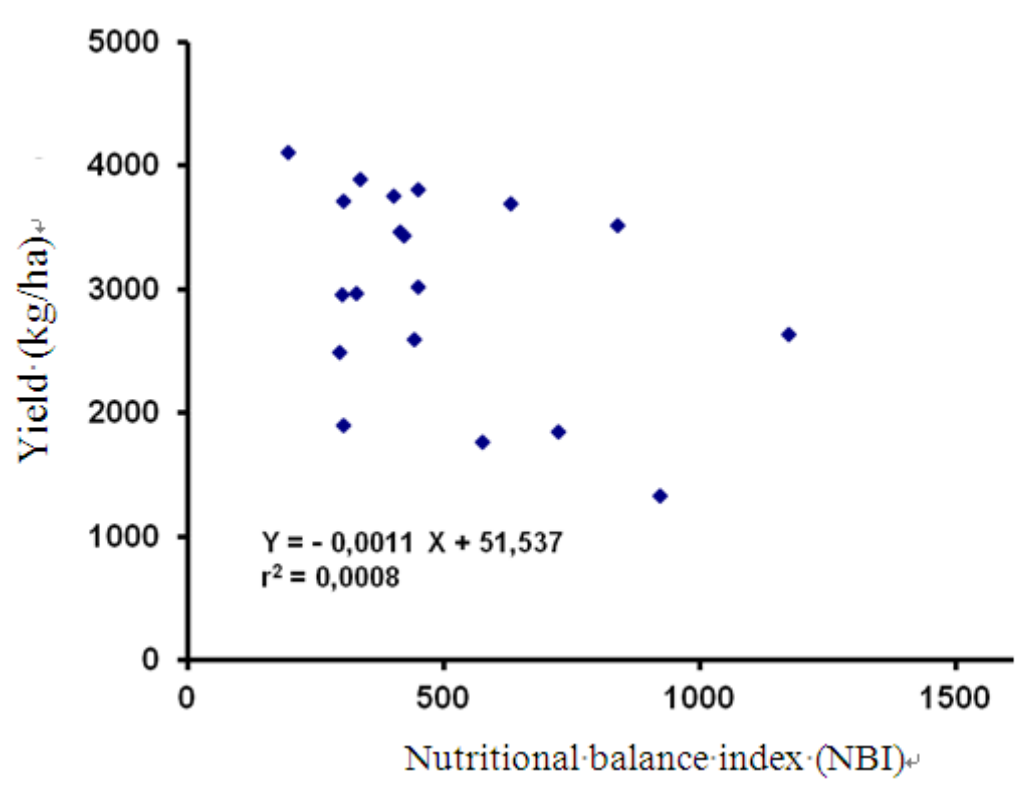

Figure 1. Correlation between yield $(\mathrm{kg} / \mathrm{ha})$ of 20 bean genotypes and the nutritional balance index (NBI)

The results of this study indicate that the DRIS is a relatively efficient methodology to determine the trustable sufficiency levels in soil, plant and in commercial crops. The DRIS performance could be explained by the fact that the forms are quite general, composed of a database with many variables, such as different genetic materials with large differences in yield potential and more (Silva et al., 2013; Wadt \& Novais, 1999).

Thus, this study showed that the DRIS analysis must take into account the cultivars, because in general each genotype showed different responses to the same fertilization.

\section{Conclusions}

1). The nutritional status of the genotypes obtained from leaf analysis are suitable for cropping.

2). The elements with high probability of response to fertilization in descending order of percentage genotypes are $\mathrm{Zn}(40 \%)>\mathrm{K}=\mathrm{B}(15 \%)>\mathrm{S}=\mathrm{Fe}(10 \%)>\mathrm{N}=\mathrm{Cu}(5 \%)>\mathrm{P}=\mathrm{Ca}=\mathrm{Mn}=\mathrm{Mg}=(0 \%)$.

3). The NBI shows no correlation with productivity for the genotypes studied.

4). The DRIS can be used to select genotypes for the efficient use of nutrients in bean production. 


\section{References}

Beaufils, E. R. (1973). Diagnosis and recommendation integrated system (DRIS). Pietermaritzburg, South Africa, University of Natal. Soil Science Bulletin, 1, 132.

Bonilla I., \& Bolaños L. (2010). Mineral Nutrition for Legume-Rhizobia Symbiosis: B, Ca, N, P, S, K, Fe, Mo, Co, and Ni: A Review. In E. Lichtfouse (Ed.), Organic Farming, Pest Control and Remediation of Soil Pollutants. Sustainable Agriculture Reviews, 1, 253-274. Netherlands: Springer. http://dx.doi.org/10.1007/978-1-4020-9654-9_13

Costa, A. N. (2002). Aplicação do sistema integrado de diagnose e recomendação (DRIS), na recomendação de adubação do feijoeiro. Embrapa-CNPAF. http://www.cnpaf.embrapa.br/negocios/ser_doc/anais/palestras/conf3.pdf

Creste J. E., \& Echer F. R. (2010). Establishing Standards for the Integrated Recommendation and Diagnosis System (DRIS) for Irrigated Bean Crops. Communications in Soil Science and Plant Analysis, 41(16), 1921-1933. http://dx.doi.org/10.1080/00103624.2010.495803

Creste, J. E., Nakagawa, J., \& Grassi Filho, H. (1999). Uso do DRIS no manejo da adubação em pomares cítricos. In: Simpósio Sobre Monitoramento Nutricional Para A Recomendação Da Adubação De Culturas, Piracicaba. Anais Piracicaba: Potafos. 1 CD-ROM.

Epstein, E. (1975). Nutrição mineral de plantas: princípios e perspectivas (p. 341). São Paulo: Universidade de São Paulo.

Fageria, N. K. (2002). Nutrient management for sustainable dry bean production in the tropics. Communications in Soil Science and Plant Analysis, 33(9-10), 1537-1575. http://dx.doi.org/10.1081/CSS-120004299

Ferreira, L. D. B. (2003). Estudo da adubação NPK no estado nutricional de Heliconia sp. (p. 73) (M.S thesis Agronomy) - Universidade de Brasília, Brasília, DF.

Lana, R. M. Q., Oliveira, S. A., Lana, A. M. Q., \& Faria, M. V. (2010). Levantamento Do Estado Nutricional de Plantas de Coffea Arabica L. pelo Dris, na Região do Alto Paranaíba Minas Gerais. Revista Brasileira de Ciencia do Solo, 34, 1147-1156. http://dx.doi.org/10.1590/S0100-06832010000400014

Malavolta, E. (1992). ABC da análise de solos e foliar (p. 124). São Paulo: Ceres.

Malavolta, E. (1987). Manual de calagem e adubação das principais culturas (p. 496). São Paulo: Ceres.

Malavolta, E., Vitti, G. C., \& Oliveira, S. A. (1998). Avaliação do estado nutricional das plantas: princípios e aplicações. (p. 201) Piracicaba: Potafos.

MAPA. (2012) Ministerio da Agricultural Pecuaria e Abastecimento do Brasil. Retrieved from http://www.agricultura.gov.br/vegetal/culturas/feijao

Oliveira, A. R., Oliveira, S. A., Goedert, W. J., \& Giordano, L. B. (2009). Avaliação de linhagens de tomateiro quanto à absorção de nutrientes e resposta à adubação. Horticultura Brasileira, 27, 1-8.

Oliveira, I. P., Araujo, R. S., \& Dutra, L. G. (1996). Nutrição mineral e fixação de nitrogênio. In R. S. Araujo, C. A. Rava, L. F. Stone \& M. J. O. Zimmermann (Eds.), Cultura do Feijoeiro Comum no Brasil (pp. 169-222). Piracicaba: Potafos.

Oliveira, S. A. (2002). Análise foliar. In D. M. G. Sousa \& E. Lobato (Eds.), Cerrado: correção do solo e adubação (pp. 245-256). Planaltina, DF: Embrapa Cerrados.

Ruas, J. (2010). Feijao, Gerência de Alimentos Básicos, Superintendência de Gestão da Oferta. Retrieved from $\mathrm{http} / / /$ www.agricultura.gov.br/arq_editor/file/camaras_setoriais/Feijao/15_reuniao/Consumo.pdf

Schulte, E. E., \& Kelling, K. A. (2002). Plant analysis: A diagnostic tool. Purdue University. Retrieved from http://www.agcom.purdue.edu/AgCom/Pubs/NCH/NCH-46.htm

Silva, E. B., Farnezi, M. M. M., Pinto, N. A. V. D., \& Grazziotti, P. H. (2013). DRIS Norms and Critical Nutrients Ranges for Coffee Beverage Quality in High Jequitinhonha Valley, Brazil. Academic Research Review, 6(1).

Silveira, R. L. V. A. (2000). Efeito do potássio no crescimento, nas concentrações dos nutrientes e nas características da madeira juvenil de progênies de Eucalyptus grandis W. Hill ex Maiden cultivadas em solução nutritiva. 182 f. (D.S. Thesis - Agronomy), ESALQ - USP, Piracicaba, SP, Brazil.

Stone, L. F., \& Satorato, A. O. (1994). O cultivo do feijão: recomendações técnicas. Brasília, Embrapa-SPI, 
(EMBRAPA - CNPAF, Documentos 48), p. 83.

Thung, M. D. T., \& Oliveira. I. P. (1998). Problemas abióticos que afetam a produção do feijoeiro e seus métodos de controle (p. 172). Santo Antonio de Goiás: EMBRAPA - CNPAF.

Wadt, P. G. S., \& Novais, R. F. (1999). O monitoramento nutricional frente aos métodos diagnósticos no planejamento das adubações. In P. G. S. Wadt \& E. Malavolta (Eds.,) Monitoramento nutricional para a recomendação da adubação de culturas. Piracicaba: Potafos (CD-ROM).

Wadt, P. G. S., Novais, R. F., Alvarez, V. H., Barros, N. F., \& Dias, L. E. (1999). Variações no estado nutricional de eucaliptos por influência do material genético e da idade da árvore. Pesquisa Agropecuária Brasileira, 34(10), 1797-1803. http://dx.doi.org/10.1590/s0100-204x1999001000005

Westermann, D., Terán, H., Muñoz-Perea, C., \& Singh, S. (2011). Plant and seed nutrient uptake in common bean in seven organic and conventional production systems. Canadian Journal of Plant Science, 91(6), 1089-1099. http://dx.doi.org/10.4141/cjps10114

\section{Copyrights}

Copyright for this article is retained by the author(s), with first publication rights granted to the journal.

This is an open-access article distributed under the terms and conditions of the Creative Commons Attribution license (http://creativecommons.org/licenses/by/3.0/). 